Ira Robinson

\title{
A Portrait of the Rabbi as a Young Man: Rabbi Pinchas Hirschprung's Memoir of His Escape from Europe to Canada
}


In November 1944, Rabbi Pinchas Hirschprung published a memoir of his escape from Nazi-held Europe entitled Fun Natsishen Yomertol: Zikhroynes fun a Polit [From the Nazi Vale of Tears: Memoirs of a Refugee]. This book is remarkable from several important perspectives. It is one of the earliest examples of Holocaust survivor memoirs, written and published while the systematic destruction of European Jewry was ongoing. It thus enables us to see the way the Holocaust was approached before the pattern of survivor memoirs was fully developed. It is also one of the rare examples of a twentieth-century Orthodox rabbinical autobiography. From an examination of his memoir, Rabbi Hirschprung obviously saw his narrative as a continuation of the chronicles of massacres and other disasters befalling Jewish communities in the past. This book enables us to perceive the ways in which a young Orthodox rabbi reacted to some of the most important moral, intellectual, and political challenges facing Jews in the twentieth century and how he attempted to relate them to previous trials and persecutions of the Jewish people.

En novembre 1944, le rabbin Pinchas Hirschprung a publié un mémoire de son évasion de l'Europe tenue par les Nazis intitulée Fun Natsishen Yomertol: Zikhroynes fun a Polit [Dans la vallée de larmes des nazis: mémoires d'un réfugié]. Ce livre est remarquable de plusieurs points de vue importants. C'est l'un des premiers exemples de mémoires de survivants de l'Holocauste, écrits et publiés alors que la destruction systématique de la communauté juive européenne était en cours. Cela nous permet ainsi de voir comment l'Holocauste a été abordé avant que le modèle des mémoires de survivants soit pleinement développé. C'est aussi l'un des rares exemples d'une autobiographie rabbinique orthodoxe du XXe siècle. D'après un examen de ses mémoires, le rabbin Hirschprung a manifestement vu dans son récit une continuation des chroniques de massacres et d'autres catastrophes survenues dans les communautés juives dans le passé. Ce livre nous permet de percevoir la manière dont un jeune rabbin orthodoxe a réagi à certains des défis moraux, intellectuels, et politiques les plus importants auxquels sont confrontés les Juifs au XXe siècle et comment il a tenté de les relier aux difficultés et persécutions précédentes du peuple juif.

Rabbi Pinchas Hirschprung (1912-1998) ${ }^{\mathrm{I}}$ was a world-renowned Torah scholar who was born in Poland, educated at Yeshivat Hakhmei Lublin, ${ }^{2}$ came to Canada in 194I, ${ }^{3}$ and ultimately served as chief rabbi of Montreal. In November of 1944, only a few years after Rabbi Hirschprung had arrived in Montreal, he published in Yiddish a memoir of his escape from Nazi-held Europe to Canada via the Soviet Union, Japan, and Shanghai entitled Fun Natsishen Yomertol: Zikhroynes fun a Polit [From the Nazi Vale of Tears: Memoirs of a Refugee]. ${ }^{4}$ As often happened with Yiddish language books published in Montreal, this memoir first appeared as a series of articles in Montreal's Yiddish daily, Der Keneder Adler, 5 and was published by the newspaper's 
press. At that time, Rabbi Hirschprung was in the beginning stages of his rise within the Montreal rabbinate to the position of head of the Rabbinical Council [va'ad harabbonim] of the Jewish Community Council [va'ad ha-ir] of Montreal, which he ultimately achieved after the decease of the previous chief rabbi of Montreal, Rabbi Sheea Herschorn, in $1969{ }^{6}$

Rabbi Hirschprung was an extraordinary man, and his book is remarkable from several important perspectives. It is one of the earliest examples of Holocaust survivor memoirs, telling the story of the first stages of Nazi persecution of the Jews of Poland at the beginning of the Second World War. It was written and published while the systematic destruction of European Jewry perpetrated by Nazi Germany was still ongoing and had become known to well-informed people in the free world, ${ }^{7}$ though its exact magnitude was still shrouded in the fog of war. Hirschprung's memoir thus enables us to see the way the Holocaust experience was approached before the entirety of the Holocaust was fully revealed to the world, and certainly before the pattern of survivor memoirs was fully developed. ${ }^{8}$ Holocaust historian Raoul Hilberg certainly distinguished reports like that of Rabbi Hirschprung from later survivor accounts and stated: "Needless to say, there were personal reports as well, but one did not think of them as testimony or memoirs."

Rabbi Hirschprung's book is also one of the rare examples of a twentieth century Orthodox rabbinical autobiography. While one may easily find many biographies of great Orthodox rabbis of Rabbi Hirschprung's era, most often written by their disciples and admirers, ${ }^{\text {Io }}$ the number of published autobiographical accounts of major twentieth century Orthodox rabbis is so small as to be almost nonexistent. when Rabbi Hirschprung introduced his memoir he gave prominent expression to his hesitation in writing such an autobiographical account because he had a feeling that writing this sort of work was not quite legitimate for a rabbi in his position (p.5). ${ }^{12}$

Rabbi Hirschprung's ultimate justification for writing his narrative despite his hesitations is also of significance. He lets his readers know that he wrote because he felt the need to chronicle his experiences insofar as they illustrated a major contemporary persecution of Jews. This orientation is clear because of the precedent he invoked to justify the publication in his own mind. The precedent he cited was Nathan Nata Hanover's well-known seventeenth century narrative of the Chmielnicki massacres of Polish and Ukrainian Jewry in 1648-9 entitled Yeven Metsula. Indeed Rabbi Hirschprung was far from the only Jew during the Holocaust and in the immediate post-Holocaust period to turn to Hanover's chronicle. Moshe Prager, another Orthodox Jew, published an account of the Nazi persecution of Polish Jewry in Tel-Aviv in I94I and entitled it Yeven Mesulah he-hadash ["The New Yeven Metsulah"].3 As historian Solomon Grayzel wrote in introducing an English translation of the chronicle published in 1950, “...one's mind naturally seeks parallels 
in our long and tragic history. The events which befell the Jews of Eastern Europe in the decade $1648-1658$ come to mind at once when one thinks of the fate of East European Jewry in modern times."'4 Hanover's translator into English, Abraham J. Mesch, further comments in his introduction, "Each time the Jew experienced a new wave of persecution, pogroms and massacres, a new edition of the Yeven Metzulah appeared." ${ }^{\text {I5 }}$ Rabbi Hischprung thus obviously saw his own narrative as a continuation of the chronicles of massacres and other disasters befalling Jewish communities in the past. ${ }^{16}$ Rabbi Hirschprung's account will thus enable us to perceive the ways in which a young Orthodox rabbi reacted to some of the most important moral, intellectual, and political challenges facing Jews in the twentieth century and how he attempted to relate them to previous trials and persecutions of the Jewish people.

As an autobiographical narrative, Rabbi Hirschprung's account forces us to confront some of the issues inherent in all autobiographies. How did he choose to present his life and experiences? What factors did he emphasize and what did he marginalize? Jacob J. Schacter, in his study of the autobiography of seventeenth century rabbi Jacob Emden, puts us on our guard as we contemplate Hirschprung's narrative when he states:

The question of the historical value of autobiography...has received a good deal of attention in the scholarly literature...Scholars have long noted the skepticism that must be attendant upon utilizing autobiography as a source of biography or history. Clearly there are many factors other than objective truth that determine how a person chooses to be remembered for posterity. ${ }^{17}$

We must also bear in mind that Rabbi Hirschprung's account must be read as a reflection of not merely his own interests but also those of the Montreal Jewish community in the period of the Second World War. In his presentation he surely had Montreal's Jews in mind as his immediate reading public. As such, his account will also enable us to discern more clearly how Montreal Jews understood themselves in relation to the wartime crisis of European Jewry, as well as how to address the question of Rabbi Hirschprung's position in the Montreal rabbinate in the years immediately following his arrival in Montreal in 194I. How did the publication of his memoir impact on this position? How did it both reflect and affect his position in the community at large?

\section{How Does Rabbi Hirschprung Choose to Portray Himself and the World He Came From?}

A good place to begin an analysis of Rabbi Hirschprung's narrative is a remark by Israel Rabinovitch, editor of the Keneder Adler, in his preface to the book (p. 3). In these introductory remarks, Rabinovitch characterized Rabbi Hirschprung's 
writing style as "temimus", a word that in the Judaic tradition had come to mean both completeness and simplicity, with additional shadings of innocence and even a touch of naïveté. Rabinovitch specifically resisted the notion that Hirschprung's style had any literary complexity [literarishe farputzung] and maintained that his narrative was rather characterized by "fullhearted plainness" [hartzike pashtus] (p.4). In his review of the book, Canadian Jewish Chronicle editor A.M. Klein essentially agreed with Rabinovitch in his portrayal of Hirschprung's prose. Klein asserted that Hirschprung wrote "simply" and "without literary frills or aesthetic gesturings," even though Hirschprung had "a cultured and learned mind" and the book was "replete with biblic verse and Talmudic parable."18 For Klein, Hirschprung's book harked back to "a Yiddish vocabulary which has passed from contemporary writing but which can still be found in Yiddish prayers and in Chassidic tales."19 From these evaluations Rabbi Hirschprung was clearly being introduced to the public as a simple rabbinic scholar who had never stepped beyond the limits of the synagogue and traditional house of study.

However, this evaluation, agreed upon by both Rabinovitch and Klein, stands in some tension with the Rabbi Hirschprung described by the same A.M. Klein in a 1942 interview in which he wrote at length and in detail of Hirschprung's mastery of general European culture and described him as anything but a simple rabbinic scholar:

For unlike the usual product of the Yeshivas, Rabbi Hirschprung has drunk deeply from the Pieran springs..$^{20}$ Proficient in the Polish language, with a knowledge of German and as much Latin as Shakespeare had, the culture of Europe has not been foreign to him...The Rabbi had occasion to refer to the writings and doings of such varied worthies as Diogenes, Plato, Spinoza, Heine, Shakespeare, Lessing, and Kant. Of the writings of Freud he has made a special study, and indeed has written several articles on the professor's dream theories for the Polish press. Nor is he unfamiliar either with the products of Haskala or of the German Yiddishe [sic]Wissenschaft. ${ }^{21}$ Rabbi Hirschprung, moreover, has found time to co-operate with the Jewish Scientific Institute [YIVO], in whose premises in Vilna he enjoyed a special office. ${ }^{22}$

In addition to Klein's positive evaluation of Rabbi Hirschprung's acquisition of European languages and culture, as well as his exposure to contemporary nonOrthodox Judaic culture, we also understand something of Rabbi Hirschprung's acquisition of general culture from the narrative itself in which Hirschprung refers in passing to his readings in Russian literature (p. I28) as well as his knowledge of the works of the Modern Hebrew poet, Hayyim Nahman Bialik (p. 180). 
Rabbi Hirschprung's writing style in Yiddish, therefore, may indeed appear to be simple and straightforward, but this stylistic "temimus" nonetheless conceals a much more complex reality. It may be possible to understand Rabbi Hirschprung's "temimus" writing style as a sort of defense of his position and dignity as an Orthodox rabbi, addressed to those in the Orthodox community of Montreal who perhaps did not think that the publication of his narrative was a worthy occupation for a rabbinic scholar [ben Torah] of his stature (p. 5).

Yet another thing the discerning reader of Rabbi Hirschprung's narrative will readily perceive is the tension between the ideal and the reality as he presents them. One can see this tension at the very beginning in his portrayal of his hometown, Dukla, located in southeastern Poland. Dukla was a small market town [shtetl] which in I880 had a Jewish population of $24 \mathrm{IO}$, constituting $80.1 \%$ of the total population; in I92I it counted 1509 Jews in a total population of $2082(72.4 \%){ }^{23}$

The book's narrative begins with Rabbi Hirschprung's portrayal of Dukla as an "ideal shtetl" from the perspective of Orthodox Judaism. In Rabbi Hirschprung's initial portrait of his shtetl (p. 7), the Jews of Dukla were described as practically uniform in their observance of the laws and traditions of rabbinic Judaism. As he put it, Dukla was, even during the weekdays, a town of the Sabbath; how much more so on the Sabbath itself. In Dukla, Hirschprung wrote, there were no public violators of the Sabbath, and no public deniers of the mores of rabbinic Judaism ['epikores]. That idyllic image certainly clashes with his later description of the Dukla pharmacist who was an assimilationist Jew (p. II2) and of the Jewish town barber who regularly gave shaves and haircuts to his Polish clients behind closed doors on Saturday afternoons. The ideal image is also betrayed by Rabbi Hirschprung's admission that Dukla possessed non-Orthodox Zionist organizations including a branch of the overtly anti-religious Zionist youth group ha-Shomer ha-Zair and at least a few individuals belonging to the socialist Zionist Poalei Zion party (p. 7). Moreover, Dukla Jews were also portrayed by Hirschprung as avid readers of the press in both Yiddish and Polish, including the left-wing Zionist-oriented Haynt, and the Revisionist-Zionist oriented Moment as well as the Orthodox-oriented Agudath Israel newspaper, Tageblatt (p. 8). ${ }^{24}$ Also in contrast to Rabbi Hirschprung's idyllic picture of his shtetl at the beginning, it soon becomes clear that Dukla was not exempt from the general depressed condition of Polish Jewry as a whole in the I930s, spiritually torn and economically ruined with many Poles boycotting Jewish stores (p. I4). ${ }^{25}$ It may well be that Hirschprung's idealization of Dukla was influenced by his reading of Hanover's Yeven Mezula which ends with an idealized portrait of Polish Jewry before its mid-seventeenth century disaster. 


\section{Cultural Influences on Rabbi Hirschprung}

While we have already discussed some of the non-rabbinic literary references in Rabbi Hirschprung's book, by far the most important non-Jewish influence for him was the Polish language and culture. Even if we did not know from the 1942 A.M. Klein interview that Rabbi Hirschprung was proficient in Polish, we would certainly have discerned it from his narrative. The narrative presents us with an Orthodox rabbi and Talmudic scholar who remembered with great fondness his boyhood education in Polish language and culture. His generational cohort had been given compulsory schooling in Polish and Rabbi Hirschprung evidently excelled in his Polish studies as much as he excelled in his study of Talmudic literature. ${ }^{26}$ Thus Hirschprung's account of the fall of the city of Krakow to the Germans on September 6, I939, included a flashback to when, as a nine-year-old schoolboy, his excellent grades in his Polish school were rewarded with a trip to Kraków accompanied by his Polish teacher and other outstanding students in his class. There he remembered seeing the major historical sites of interest including the grave of prominent Polish poet Adam Mickiewicz, Wawel Castle, the seat of Polish kings, Wawel Cathedral with its golden roof, the graves of Polish kings, as well as the Jewish town (p. 35).

His excellent education in Polish meant that Rabbi Hirschprung was able to communicate easily with non-Jewish Poles and in his narrative he counts the local Catholic priest in Dukla as a personal friend (p. 3I). His mastery of the language also positioned Hirschprung in the days prior to the outbreak of war to serve as interpreter and intermediary between his grandfather the town rabbi and the general in command of the Polish forces assembled at Dukla to defend the strategic Dukla Pass against an imminent German invasion (p. I2).

In Rabbi Hirschprung's narrative another decidedly non-rabbinic influence makes its presence known - suicide ${ }^{27}$ Confronting the enormity of the Nazi threat to Jewish life and well-being, even before the German plan to systematically kill all the Jews in their power was fully comprehended, and despite his certain knowledge that suicide was stringently forbidden by Judaic law [halakha], Rabbi Hirschprung records in his narrative several points at which he entertained thoughts of suicide. The first time was just prior to the Nazi capture of Dukla (p. 48). A second time was when he was briefly incarcerated in a German concentration camp (p. II7). Yet a third instance of Rabbi Hirschprung's thoughts of suicide occurred in Vilna, at a point where he felt that all possible routes of escape to the free world had been shut off completely (p. 213).

Rabbi Hirschprung also reveals a great deal about his orientation to some of the great political issues of his era. It is certainly to be expected that he would oppose Hitler and Nazism, and indeed he records that he regularly received anti-Nazi literature 
which he destroyed as "incriminating evidence" prior to the German army entering Dukla and beginning the destruction of its Jewish community (p. 48). ${ }^{28}$

However, what is quite unexpected on the part of an Orthodox yeshiva student and rabbi is his positive orientation toward the ideology of the Soviet Union communism. This is quite surprising since the Soviet communist suppression of religion in general and of Judaism in particular (especially by Jewish communists) would have been well known to him. ${ }^{29}$ Hirschprung's pro-communist orientation clearly appears during that part of the narrative in which he wanders through the Soviet-occupied zone in Eastern Poland..$^{\circ}$ At the very beginning of his trek he is favorably impressed by a group of Red Army soldiers who gave him a lift in their truck (p. I25). This incident causes him to remember how when he was a youngster he was impressed by the poverty and plight of the peasants and thought that there should be a more just political and economic system (p. I26). As he matured, Hirschprung's friends influenced him to read more about socialism and he read and was particularly influenced by the arguments of Professor Ferdinand Ossendowski in his book on Lenin (p. I27). ${ }^{3 \mathrm{I}}$ In Soviet-occupied Poland, Rabbi Hirschprung describes himself as a "religious communist" (who nonetheless wished to be free to observe the Sabbath and the other religious commandments of Judaism) (pp. I43, I65).

While surprising, Rabbi Hirschprung's pro-Soviet attitude needs to be read in the context of the moment in history in which it was written. I944 was in many ways the height of the alliance among the Allied Powers, chief among which were the United States, Great Britain, and the Soviet Union. The fact that in 1944 Soviet Armies were instrumental in fighting and defeating Germany on the Eastern Front translated not merely into great sympathy and friendship for the Soviet Union among Canadian Jews, ${ }^{32}$ but also into electoral strength for Jewish Communists and their sympathizers in Canada. Thus in 1943 Communist Fred Rose was elected to the Canadian House of Commons from a heavily-Jewish riding in Montreal,33 and in the same year Joe Salsberg was elected to the Ontario Legislature from a Jewish riding in Toronto. ${ }^{34}$ This moment did not last long because the Cold War between the Soviet Bloc and the Western Democracies would soon enough drive Communists from Canadian legislative bodies, and Jewish communists from the organized Canadian Jewish community, 35 but precisely in 1944 the Soviet Union was a heroic ally and its ideology was far from anathema on the Canadian Jewish street.

There is much valuable material contained in Rabbi Hirschprung's book. For historians of the Holocaust, there is a detailed description of the initial period of the German occupation of Dukla. This is a period which in other first-person accounts of the Holocaust is often less emphasized than later, more destructive periods the authors lived through. For historians of Orthodox Judaism and in particular the Yeshiva movement, there is an invaluable detailed first-person account of the development 
of yeshiva life in Lithuania in the years 1939-I94I and in particular of the religious leadership of Rabbi Hayyim Ozer Grodzinski of Vilna just prior to his death in $1940 .^{36}$ It is also a major primary source for the escape of hundreds of yeshiva scholars from Vilna through the Soviet Union and Japan to Shanghai. ${ }^{37}$

In a larger sense, Rabbi Hirschprung's memoir of his experiences in the years I939I94I has much to say to us about its historical moment, a moment when Jews had just begun assimilating and reacting to the enormity of the Nazi destruction of European Jewry and were searching for a vocabulary to describe this disaster and a framework in which to place it..$^{8}$ In a certain sense this search began in 1944 with Rabbi Hirschprung's book. It continues to this day.

1

On Rabbi Hirschprung, see Ira Robinson, "Hirschprung, Pinhas." Encyclopaedia Judaica Ed. Michael Berenbaum and Fred Skolnik, second edition Volume 9 (Detroit: Macmillan Reference USA, 2007), p. 141. Cf. David Abraham Mandelbaum, "Toledot ha-G[aon] Rabi Pinhas Hirschprung zts'l" in Shlomo Gottesman, ed., Yeshurun (New York and Jerusalem, Makhon Yeshurun, 2012), pp. 155-193.

\section{2}

Shaul Stampfer, Families, Rabbis and Education: Traditional Jewish Society in Nineteenth-Century Eastern Europe (Oxford, Littman Library of Jewish Civilization, 2010), pp. 267-268; Nahman Shemen, Lublin: City of Torah, Rabbinism and Piety [Yiddish] (Toronto, Gershon Pomerantz, 1951), pp. 98-105; David A. Mandelbaum, Yeshivat hakhme Lublin : ha-yeshivah u-meyasdah Maharam Shapira (Jerusalem and Tel Aviv, ha-Merkaz le-'idud mif'ale tarbut u-mehḳarim toraniyim beYiśra'el, 1993).

\section{3}

On the complicated efforts to get Rabbi Hirschprung and his fellow refugee rabbinic scholars to Canada, see Irving Abella and Harold Troper, None Is Too Many: Canada and the Jews of Europe, 1933-1948 (Toronto, Lester and Orpen Dennys, 1982), pp. 94-97; Ephraim Zuroff, The response of Orthodox Jewry in the United States to the Holocaust : the activities of the Vaad ha-Hatzala Rescue Committee, 1939-1945(New York, KTAV, 2000), pp. 170-190.

\section{4}

An English version of Rabbi Hirschprung's book, translated by Vivian Felsen, has recently been published. It is entitled The Vale of Tears (Toronto, Azrieli Foundation, 2016). The original Yiddish book is available online: http://www.yiddishbookcenter.org/collections/ yiddish-books/spb-nybc207731/hirschprungp-fun-natsishen-yomertol-zikhroynes-fun-apolit [accessed February 24, 2016].

\section{5}

The book was serialized in the Keneder Adler from May to August, 1944. Segments of the narrative appeared in the newspaper twice a week on average. On this newspaper and its community see Rebecca Margolis, Jewish Roots, Canadian Soil, Yiddish Culture in Montreal, 1905-1945 Montreal and Kingston, McGill-Queen's University Press, 2011 ), pp. 39-74.

\section{6}

On Rabbi Herschorn, see Ira Robinson, "Herschorn, Joshua (Sheea) Halevy", Encyclopedia Judaica Ed. Michael Berenbaum and Fred Skolnik, second edition (2007), volume 9, p. 44; idem., "'The Other Side of the Coin': The Anatomy of a Public Controversy in the Montreal Jewish Community, 1931", Studies in Religion 40 Issue 3 (September $2011)$ pp. 271 - 282.

\section{7}

On the state of knowledge of the Holocaust in North America prior to the end of the war, see Deborah E. Lipstadt, Beyond Belief: The American Press and the Coming of the Holocaust, 1933-1945 (New York, Free Press, 1986). 
8

Cf. David Roskies, Holocaust Literature: A History and Guide. With Naomi Diamant. (Hanover, NH: Brandeis University Press, 2012).

\section{9}

Raoul Hilberg, "The Development of Holocaust Research-a Personal Overview", in David Bankier and Dan Michman, eds., Holocaust Historiography in Context: Emergence, Challenges, Polemics, and Achievements (Jerusalem, Yad Vashem, 2008), p. 25. For an example of such an early report, see S. Mendelsohn, "The Battle of the Warsaw Ghetto" (New York, YIVO, 1944).

\section{0}

These Orthodox biographies often verge into hagiography. Rabbi Berel Wein comments: "Much of Orthodoxy is ...hagiographic about its present and past leaders." "The Past And The Present", http://www.rabbiwein.com/ blog/post-1598.html [accessed February $26,2016]$. Isadore Twerky observes that traditional Jewish conceptions tend to blur the individuality of rabbinic scholars. Thus all great rabbis, in a sense, partake of the characteristics of the basic paradigm of "the rabbi." Isadore Twersky, Introduction to the Code of Maimonides (New Haven, Yale University Press, 1980), p. 92.

\section{1}

The major exceptions to this rule are the autobiographies of Rabbi Baruch ha-Levi Epstein, and Rabbi Joseph Isaac Scheersohn. Rabbi Epstein's memoir is Meḳor Barukh : 'im zikhronot me-haye ha-dor ha-kodem ve-'im mavo gadol Talmudi ve-sifruti (Vilna, 1926).

Selections from this book were translated into English: My Uncle The Netziv : Rabbi Baruch Halevi Epstein, The Author Of Torah Temimah, Recalls His Illustrious Uncle, Rabbi Naftali Zvi Yehudah Berlin, And The Panorama Of His Life (Brooklyn, Masorah Publications, 1986). Rabbi Schneersohn's memoir is Sefer hazikhronot. It has been translated into English as Lubavitcher Rabbi's Memoirs: the Memoirs of Joseph I. Schneersohn 2 volumes (Brooklyn, N.Y., Otzar Hachassidim, 1956-1960).

\section{2}

All page references are to the Yiddish edition of the book.
13

On Prager, see Havi Dreifuss, “Jewish Historiography of the Holocaust in Eastern Europe", Polin 29 (2017), p. 219.

14

Solomon Grayzel, "Preface” to Nathan Hanover, Abyss of Despair (New York, Bloch Publishing Company, 1950), p. x.

15

Abraham J. Mesch, "Introduction" to Nathan Hanover, Abyss of Despair (New York, Bloch Publishing Company, 1950), p. 11.

\section{6}

On these chronicles and their significance, see Yosef Haim Yerushalmi, Zakhor: Jewish History and Jewish Memory (Seattle, University of Washington Press, 1996).

17

Jacob J. Schacter, “History and Memory of Self: the Autobiography of Rabbi Jacob Emden", in Elisheva Carlebach et al., eds., Jewish History and Jewish Memory: Essays in Honor of Yosef Haim Yerushalmi (Hanover, Brandeis University Press, 1998), pp. 438-439. Cf. Michael Stanislawski, Autobiographical Jews: Essays In Jewish Self-Fashioning (Seattle, University of Washington Press, 2004).

\section{8}

Abraham M. Klein, "Had the Torah Not Been My Delight..." A clipping of the review, which appeared in the Canadian Jewish Chronicle but which is undated is found in Rabbi Hirschprung's file in the Jewish Canadiana collection, Jewish Public Library, Montreal. 19 lbid.

20

"Pierian Springs" is a classical reference, understood to be a metaphor for knowledge of the arts and science.

21

Modern Judaic studies.

22

Abraham M. Klein, “A Great Talmudist: Rabbi Pinchas Hirschprung Interviewed" Canadian Jewish Chronicle March 13, 1942. 
23

On Dukla's Jewish community, see Andrzej

Potocki, Podkarpackie Judaica (Brzozow,

Poland, 1993), pp. 19, 60.

\section{4}

On the Polish Jewish press in this era, see Avraham Greenbaum, "Newspapers and Periodicals" YIVO Encyclopedia of Jews in Eastern Europe http://www.yivoencyclopedia. org/article.aspx/Newspapers_and_Periodicals [accessed February 16, 2016].

\section{5}

Cf. Celia S. Heller, On The Edge Of Destruction: Jews Of Poland Between The Two World Wars (New York, Columbia University Press, 1977).

\section{6}

On Polish language education and its influence on Jewish children in interwar Poland, see Gershon Bacon, "National Revival, Ongoing Acculturation--Jewish Education in Interwar Poland," Simon Dubnow Institute Yearbook 1 (2002), pp. 71-92.

\section{7}

On the issue of suicide with respect to twentieth century Polish Jewry, see Daniel Rosenthal, "Victims of Seductive and Unfortunate Lives: Jewish Suicide in Interwar Poland" Jewish History 29 (2015) pp. 301-330.

\section{8}

On the German Army's violence against Jews in the September 1939 invasion of Poland, see Alexander B. Rossino, "Destructive Impulses: German Soldiers and the Conquest of Poland" Holocaust and Genocide Studies (1997) 11 (3): 351-365.

\section{9}

On the suppression of Judaism in the Soviet Union in its early years see Mordechai Altshuler, Ha-Yevsektsyah bi-Verit-ha-Mo'azot (1918-1930): Ben le'umiyut le-komunizm (Jerusalem, 1980).

\section{0}

On Polish Jews under Soviet occupation, see Dov Levin, The Lesser of Two Evils: Eastern European Jewry Under Soviet Rule, 1939-1941 (Philadelphia, Jewish Publication Society, 1995).

\section{1}

Ossendowski's book was published in English as Lenin: God of the Godless (New York, E.P.

Dutton, 1931).
32

See, for instance, an article by Israel Medres, "Kanadish-Sovyetish Frayndshaft" [CanadianSoviet Friendship], Keneder Adler July 4, 1944, p. 4.

33

Gerald Tulchinsky, Canada's Jews: a People's Journey (Toronto, University of Toronto Press, 2008), pp. 268-270.

\section{4}

Gerald Tulchinsky, Joe Salsberg: a Life of Commitment (Toronto : University of Toronto Press, 2013), p. 67ff.

\section{5}

On Canadian Jewish Communists and their sympathizers, see Ester Reiter, A Future Without Hate or Need: The Promise of the Jewish Left in Canada (Toronto, Between the Lines, 2016).

\section{6}

On Rabbi Grodzinski and his leadership see Gershon C. Bacon, "Rubinstein vs. Grodzinski: The Dispute over the Vilnius Rabbinate and the Religious Realignment of Vilnius Jewry, 19281932," in The Gaon of Vilnius and the Annals of Jewish Culture (Vilnius, 1998), pp. 295-304.

\section{7}

On this escape, see David A. Mandelbaum, Gibborei ha- Hayil: Yeshivat Hakhmei Lublin beTekufat ha-Sho'a (Bnei Brak, ha-Modia, 2010)

2 volumes. The book was adapted into English as From Lublin to Shanghai: the Miraculous Exile of Yeshivas Chachmei Lublin (New York, Mesorah Publications, 2012).

\section{8}

On the initial North American reaction to the enormity of the Holocaust, see Hasia R. Diner, We Remember With Reverence and Love: American Jews and The Myth Of Silence After The Holocaust, 1945-1962 (New York, New York University Press, 2009). 